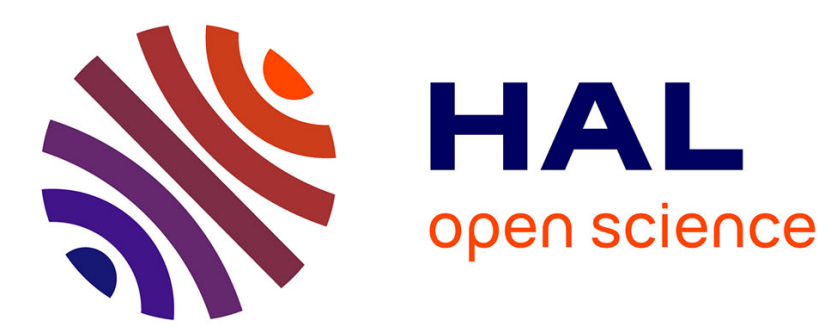

\title{
Growth of Cu2SnS3 thin films by solid reaction under sulphur atmosphere
}

M Bouaziz, J Ouerfelli, S.-K. Srivastave, Christian Bernède, Mosbah Amlouk

\section{To cite this version:}

M Bouaziz, J Ouerfelli, S.-K. Srivastave, Christian Bernède, Mosbah Amlouk. Growth of Cu2SnS3 thin films by solid reaction under sulphur atmosphere. Vacuum, 2011, 85 (8), pp.783-786. 10.1016/j.vacuum.2010.10.001 . hal-03345087

\section{HAL Id: hal-03345087 \\ https://univ-angers.hal.science/hal-03345087}

Submitted on 15 Sep 2021

HAL is a multi-disciplinary open access archive for the deposit and dissemination of scientific research documents, whether they are published or not. The documents may come from teaching and research institutions in France or abroad, or from public or private research centers.
L'archive ouverte pluridisciplinaire HAL, est destinée au dépôt et à la diffusion de documents scientifiques de niveau recherche, publiés ou non, émanant des établissements d'enseignement et de recherche français ou étrangers, des laboratoires publics ou privés. 


\title{
Growth of $\mathrm{Cu}_{2} \mathrm{SnS}_{3}$ thin films by solid reaction under sulphur atmosphere
}

\author{
M. Bouaziz ${ }^{\text {a }}$, J. Ouerfelli ${ }^{\text {a }}$, S.K. Srivastava ${ }^{b}$, J.C. Bernède ${ }^{c}$, M. Amlouk $^{\mathrm{a}, *}$ \\ ${ }^{a}$ Unité de Physique des Dispositifs à Semi-conducteurs, Faculté des Sciences de Tunis, Tunisia \\ ${ }^{\mathrm{b}}$ Inorganic Materials and Nanocomposites Laboratory, India Institute of Technology, Kharagpur 721302, India \\ ${ }^{c}$ LAMP, Faculté des Sciences et Techniques, 2 rue de la Houssinière, 44000 Nantes, France
}

\section{A R T I C L E I N F O}

\section{Article history:}

Received 15 June 2010

Received in revised form

28 September 2010

Accepted 6 October 2010

Keywords:

Thin films

$\mathrm{Cu}_{2} \mathrm{SnS}_{3}$

Ternary systems

Optical properties

\begin{abstract}
A B S T R A C T
$\mathrm{Cu}_{2} \mathrm{SnS}_{3}$ thin film have been synthesized by solid state reaction under vapour sulphur pressure at $530{ }^{\circ} \mathrm{C}$, during $6 \mathrm{~h}$, via a sequentially deposited copper and tin layers $\mathrm{Cu} / \mathrm{Sn} / \mathrm{Cu} \ldots . \mathrm{Sn} / \mathrm{Cu} / \mathrm{Sn}$. The structure and the composition were characterized by X-Ray Diffraction (XRD), Scanning Electron Microscopy (SEM) and Electron Probe Micro Analysis (EPMA). X-ray diffraction revealed that as the deposited film crystallizes in the cubic structure and the crystallites exhibit preferential 111 orientation of the grains. Moreover, EPMA analysis confirmed that the obtained film is stoichiometric. The SEM study shows the presence of spherical particles of $\approx 100-120 \mathrm{~nm}$ diameters. The optical absorption coefficient and band gap of the film were estimated by means of transmission and reflection optical measurements at room temperature. A relatively high absorption coefficient in the range of $10^{4} \mathrm{~cm}^{-1}$ was indeed obtained and the band gap value is of the order of $1.1 \mathrm{eV}$. On the other hand, the electrical conductivity of $\mathrm{Cu}_{2} \mathrm{SnS}_{3}$ film prepared in the present experiment is suitable for fabricating a thin film solar cell based on not cheaper and environmental friendly material.
\end{abstract}

(ㄷ) 2010 Elsevier Ltd. All rights reserved.

\section{Introduction}

In recent years, there has been a great deal of interests in the research of nontoxic semiconductors both from a fundamental as well as technological point of view. $\mathrm{Cu}-\mathrm{Sn}-\mathrm{S}$ systems are members of the I-IV-VI group of semiconductors which attracted some attention because of their interesting properties [1-6] and their potential applications as small band semiconductors and as suitable candidate for nonlinear optical materials and in photovoltaic cells [7-11]. Many of semiconducting multicomponent phases have been reported in this system, such as $\mathrm{Cu}_{4} \mathrm{SnS}_{4}$ [12], $\mathrm{Cu}_{2} \mathrm{SnS}_{3}$ [9,13-15], $\mathrm{Cu}_{4} \mathrm{Sn}_{7} \mathrm{~S}_{16}$ [9], $\mathrm{CuSn}_{3.75} \mathrm{~S}_{8}$ [16], $\mathrm{Cu}_{3} \mathrm{SnS}_{4}$ [17]. $\mathrm{Cu}_{2} \mathrm{SnS}_{3}$ ternary semiconducting material is one of the most promising semiconductor materials which can be used in solar cells due to its band gap close to that expected for photovoltaic solar energy conversion and its high absorption coefficients [15]. The preparation of $\mathrm{Cu}_{2} \mathrm{SnS}_{3}$ has been reported in micro- as well as in nanocrystalline forms $[5,18-20]$. The only attempts in thin films were by using the spray pyrolysis technique [15], or by evaporation of the powdered $\mathrm{Cu}_{2} \mathrm{SnS}_{3}$ [21]. However, the films prepared by Kuku et al. [21] were deficient in copper. So, even double evaporation technique involving $\mathrm{Cu}_{2} \mathrm{SnS}_{3}$ and copper could not provide

\footnotetext{
* Corresponding author. Tel.: +216 71872 600; fax: +216 71885073 .

E-mail address: Mosbah.Amlouk@fsb.rnu.tn (M. Amlouk).
}

stoichiometric films of $\mathrm{Cu}_{2} \mathrm{SnS}_{3}$. Nevertheless, not much has been explored in finding other alternative ways to deposit single phase $\mathrm{Cu}_{2} \mathrm{SnS}_{3}$ thin film $[17,22]$.

The aim of this study is to establish the optimized experimental conditions needed to prepare stoichiometric $\mathrm{Cu}_{2} \mathrm{SnS}_{3}$ films using a solid state reaction. It has been achieved by annealing, in sulphur atmosphere, of sequentially deposited of copper/tin sandwich layers. The films have been characterized by X-ray diffraction (XRD), microprobe analysis and scanning electron microscopy (SEM). The electrical and optical properties of the film have also been investigated.

\section{Experimental details}

The optimized $\mathrm{Cu}_{2} \mathrm{SnS}_{3}$ film was deposited by a sequential thermal evaporation onto glass substrate. The working pressure was maintained at about $10^{-4} \mathrm{~Pa}$.

\subsection{The deposition of $\mathrm{Cu}_{2} \mathrm{SnS}_{3}$ thin film was accomplished in two stages}

In the first stage, four bi-evaporated layers of $\mathrm{Cu} / \mathrm{Sn}$ were grown using two separated crucibles containing high purity $\mathrm{Cu}$ and $\mathrm{Sn}$ and which were mounted horizontally, each of them being at a corner of an equilateral triangle, while the sample holder was situated at the third one. The crucible-to-substrate distance was adjusted to $10 \mathrm{~cm}$. 


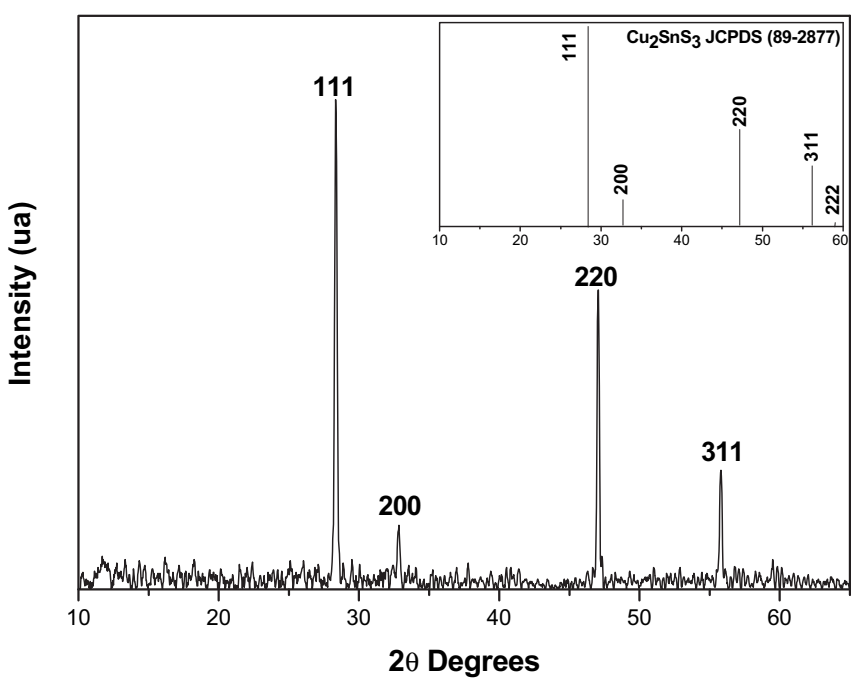

Fig. 1. X-ray diffraction pattern of $\mathrm{Cu}_{2} \mathrm{SnS}_{3}$ thin film obtained at $530{ }^{\circ} \mathrm{C}$.

The substrate temperature during the deposition of $\mathrm{Cu}$ was maintained at $150{ }^{\circ} \mathrm{C}$ and they were subsequently cooled down to room temperature for the deposition of the Sn layer. The thicknesses of each layer of: $\mathrm{Cu}$ and $\mathrm{Sn}$ were approximately 100 and $60 \mathrm{~nm}$ respectively.

In the second stage, the simple is sealed in glass tube under a vacuum of $10^{-2} \mathrm{~Pa}$ with sulphur bulk and it was submitted to a thermal annealing in sulphur environment at $530{ }^{\circ} \mathrm{C}$ for $6 \mathrm{~h}$.

The XRD of the sample was recorded by using a Siemens D500 powder diffractometer with $\mathrm{Cu} \mathrm{K} \alpha$ radiation. The average crystallite size $(t)$ corresponding to $(h k l)$ reflections has been calculated by using the Scherrer's equation as follows:

$t=\frac{K \lambda}{\beta \cos \theta}$

Where, the constant $K$ is a shape factor and has been taken equal to $0.9, \lambda$ is the wavelength of the X-ray, $\beta_{2 \theta}$ is the FWHM corresponding to the Bragg's angle $\theta$.

The surface topography and the composition of prepared film have been obtained using a JEOL F-6400 and a JEOL F-5800 LV respectively. The optical characteristics were determined with SHIMADZU 3100S UV/VIS spectrophotometer in the range of 300-1800 nm. Finally, the electrical parameters, including conductivity and conductivity type, were determined by the two probes and hot point probe techniques respectively.

\section{Results and discussion}

\subsection{X-ray diffraction}

It was noted that the original white colour of Sn at the surface of the $\mathrm{Cu} / \mathrm{Sn}$ metallic precursor changed to grey colour when sulphurized. Such grey colour is expected for $\mathrm{Cu}_{2} \mathrm{SnS}_{3}$ films. Fig. 1, shows the X-ray diffractogram of the deposited film annealed at

Table 1

Ratio of $I_{\mathrm{hk} 1} / I_{111}$ for $\mathrm{Cu}_{2} \mathrm{SnS}_{3}$ thin films and powder.

\begin{tabular}{lll}
\hline $\mathrm{I}_{h k l} / \mathrm{I}_{111}$ & $530{ }^{\circ} \mathrm{C}$ & JCPDS (89-2877) \\
\hline$I_{200} / I_{111}$ & 0.135 & 0.128 \\
$I_{220} / I_{111}$ & 0.617 & 0.485 \\
$I_{311} / I_{111}$ & 0.243 & 0.298 \\
\hline
\end{tabular}

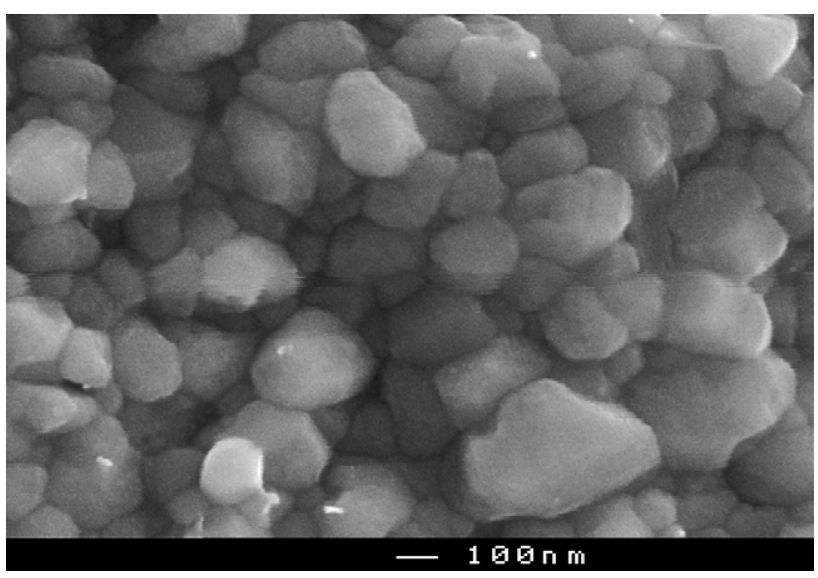

Fig. 2. SEM micrographs of $\mathrm{Cu}_{2} \mathrm{SnS}_{3}$ thin film obtained at $530{ }^{\circ} \mathrm{C}$.

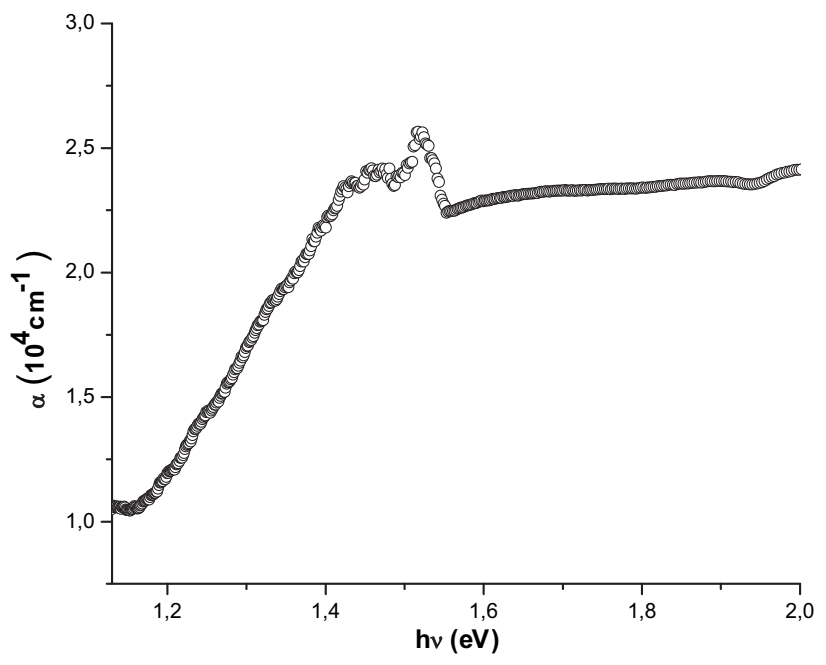

Fig. 3. Variation of absorption coefficient $(\alpha)$ with wavelength for $\mathrm{Cu}_{2} \mathrm{SnS}_{3}$ thin film.

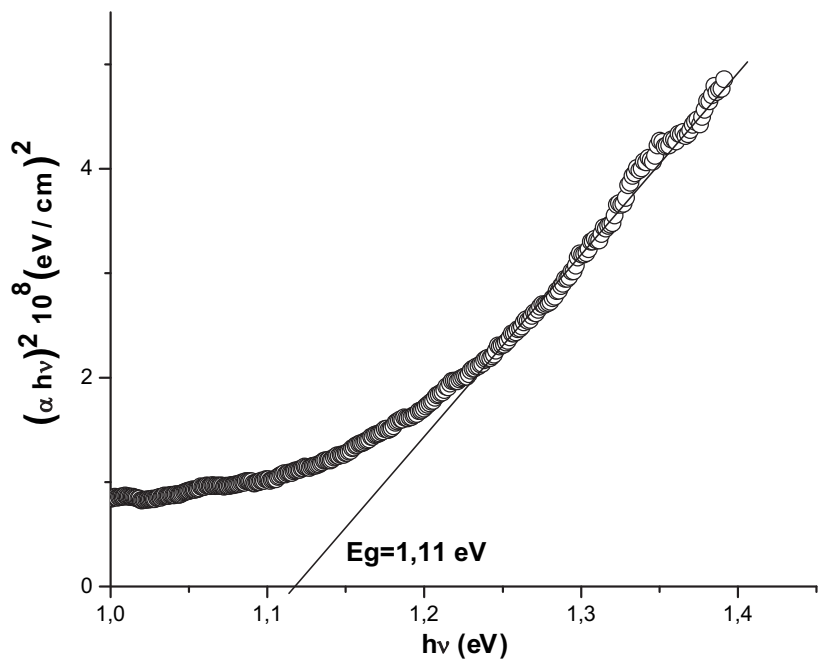

Fig. 4. $(\alpha \mathrm{h} v)^{2} \mathrm{vs}$. $\mathrm{h} v$ for the films of $\mathrm{Cu}_{2} \mathrm{SnS}_{3}$ obtained at $530{ }^{\circ} \mathrm{C}$. 

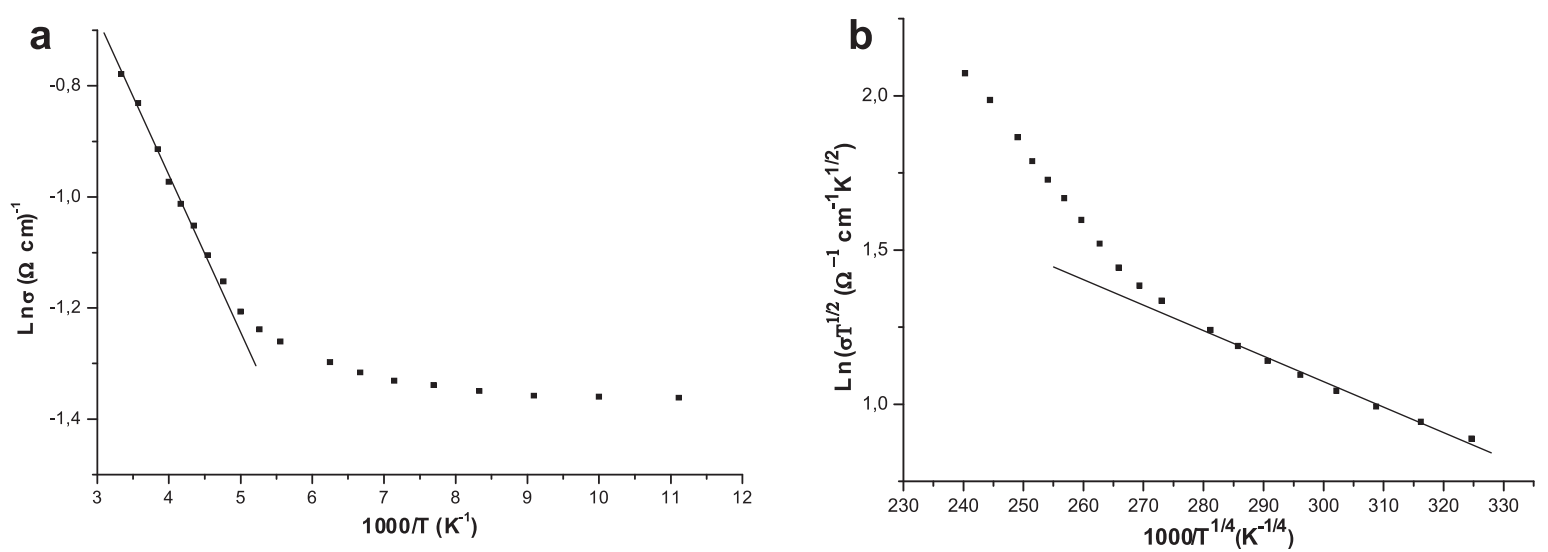

Fig. 5. a. Plot of $\ln \sigma$ vs. $1000 / \mathrm{T}$ for the $\mathrm{Cu}_{2} \mathrm{SnS}_{3}$ thin film. b. Replot of the data in Fig. $5 \mathrm{a}$ as $\ln \left(\sigma \mathrm{T}^{1 / 2}\right) \mathrm{vs} .1000 / \mathrm{T}^{1 / 4}$.

$530{ }^{\circ} \mathrm{C}$ for $6 \mathrm{~h}$. All the observed diffraction peaks can be indexed to a single phase of $\mathrm{Cu}_{2} \mathrm{SnS}_{3}$ with lattice constants very close to the cubic phase ( $a=5.430 \mathrm{~nm}$ ) according to JCPDS file [23]. EPMA analysis of the film shows $\mathrm{Cu}: \mathrm{Sn}: \mathrm{S}$ atomic ratios to be $2: 1: 3$ in conformity with the identified phase by XRD. It is clear from the diffractogram in Fig. 1 that the 111 diffraction peak is of most intense. The other peaks observed in the diffractogram correspond to 200,220 and 311 directions. The diffraction peak intensity ratios of $I_{h k l} / I_{111}$ have been calculated and the results are compared in Table 1 with those of a $\mathrm{Cu}_{2} \mathrm{SnS}_{3}$ reference polycrystalline powder. It can be seen that the ratios $I_{h k l} / I_{111}$ for the film annealed at $530{ }^{\circ} \mathrm{C}$ are very close to the reference values. When the sequential deposition was modified with $\mathrm{Sn}$ as first layer the ternary compound was not obtained and we obtain a sample with a CuS phase and a low Sn content due to the strong tendency of Sn evaporation during the $\mathrm{Cu}$ deposition.

The size of the crystallites in the film relative to the $h k l$ directions and calculated using Scherrer's equation lies in $35-45 \mathrm{~nm}$ domain.

\subsection{Scanning electron micrograph}

A scanning electron micrograph of the film annealed at $530{ }^{\circ} \mathrm{C}$ under sulphur pressure is shown in Fig. 2. It can be seen that the film is homogeneous with no visible cracks or holes. The grains of $\mathrm{Cu}_{2} \mathrm{SnS}_{3}$ exhibit spherical shape with diameters lying in the range of 200-300 $\mathrm{nm}$. The grain sizes measured by X-ray are smaller than that statistically estimated from SEM. The discrepancy can be attributed to the fact that the grains visualized by SEM are constituted of more than one crystallite. Such observations have been observed in many cases [24,25]. The thickness of the deposited film is about $0.9 \mu \mathrm{m}$.

\subsection{Optical properties}

The optical absorption coefficient $(\alpha)$ of $\mathrm{Cu}_{2} \mathrm{SnS}_{3}$ film has been calculated using the well known expression [26]:

$\alpha_{\lambda}=\frac{1}{t}\left(\frac{\left(1-R_{\lambda}\right)^{2}}{T_{\lambda}}\right)$

It was found that $\alpha$ value was about $10^{4} \mathrm{~cm}^{-1}$, Fig. 3 .

Fig. 4 shows a characteristic plot of the variation in $(\alpha h \nu)^{2}$ with photon energy $h \nu$ near the fundamental edge. As we can see, for optically measured film we found a linear dependence indicating an allowed direct transition with: $\alpha h \nu=A\left(h \nu-E_{\mathrm{g}}\right)^{1 / 2}$

Where $E_{\mathrm{g}}$ is the band gap, $A$ a constant. The gap energy was estimated by extrapolating $(\alpha h \nu)^{2}$ vs. $h \nu$ to zero to be equal to $1.11 \mathrm{eV}$.

This value is in good agreement with the reported data on bulk polycrystalline as well as for the $\mathrm{Cu}_{2} \mathrm{SnS}_{3}$ films prepared either by spray and reported in our previous work [15] or by other methods $[5,20,22]$. Such value of the band gap is quite close to the optimum band gap for solar cells, which makes it a very promising absorber material in future solar cells.

\subsection{Electrical properties}

Fig. 5 exhibits the variation of electrical conductivity of $\mathrm{Cu}_{2} \mathrm{SnS}_{3}$ thin film sulphurized at $530{ }^{\circ} \mathrm{C}$ with the inverse of absolute temperature. From the plot, we find that the conductivity of the film increases with increase of temperature indicating the semiconducting behavior of the sample. The increase of conductivity is gradual near the room temperature range. Similar observations have been reported previously $[27,28]$.

The presence of two regions with different slopes in the plot suggests that there are two types of conduction mechanism present in $\mathrm{Cu}_{2} \mathrm{SnS}_{3}$ film deposited by a solid state reaction of $\mathrm{Cu}$, Sn and $\mathrm{S}$. The point of inflection is found to be around $238 \mathrm{~K}$. In the temperature region below $238 \mathrm{~K}$, the conduction is due to a variable range hopping mechanism following Mott's law: [29]

$\sigma \propto T^{-1 / 2} \exp \left[-\left(T_{0} / T\right)^{1 / 4}\right]$

Whereas, in the temperature region above $238 \mathrm{~K}$, the electrical conductivity varies linearly with temperature. Data can be fitted to Arrhenius's law:

$\sigma \propto \exp \left(-E_{\mathrm{a}} / k T\right)$

and it is attributed to a thermal excitation of charge carriers. These results seem to agree well with those observed in such chalcopyrite as: CuInS ${ }_{2}$, CuInSe $_{2}$ [30]. The activation energy $E_{\mathrm{a}}$ is around $25 \mathrm{meV}$.

The results reveal that the films are stable and p-type conductivity of the sample has been checked by the hot point probe technique.

\section{Conclusion}

The purpose of our work was to gain experience with a new preparation technique of $\mathrm{Cu}_{2} \mathrm{SnS}_{3}$ thin film achieved by sulphurization of a metallic precursor constituted of sequentially deposited 
$\mathrm{Cu} / \mathrm{Sn} / \ldots \mathrm{Cu} / \mathrm{Sn}$ multilayer and annealed under sulphur pressure for $6 \mathrm{~h}$ at $530{ }^{\circ} \mathrm{C}$. Structural, morphological, optical and electrical properties of the optimized sample have been investigated. The obtained results show that this is a promising starting point for future investigations of $\mathrm{Cu}_{2} \mathrm{SnS}_{3}$ non toxic thin film instead of CIS and CIGS, classical materials in the fabrication of high performance photovoltaic devices.

\section{References}

[1] Samanta LK, Ghosh DK, Bhar GC. Phys Status Solidi 1986;93. K51.

[2] Disalvo FJ. Science 1991;247:649.

[3] Lee JJ, Yang CS, Park YS, Kim KH, Kim WT. J Appl Phys 1999;86:2914

[4] Sheldrick WS, Wachhold M. Angew Chem Int Ed Engl 1997;36:206.

[5] Onoda M, Chen XA, Sato A, Wada H. Mater Res Bull 2000;35:563.

[6] Marcano G, Chalbaud LM, Rincon C, Sanchez Perez G. Mater Lett 2002;90:1847.

[7] Aliev SN, Magomedov YB, Shchegol'kova NV. Sov Phys Semiconduct 1986; 1971:4.

[8] Khanafer M, Gorochov O, Rivet J. Mater Res Bull 1974;9:1543.

[9] X-a Chen, Wada H, Sato A, Mieno M. J Solid State Chem 1998;139:144

[10] Samanta LK. Phys Status Solidi 1987;100. K93.

[11] Kazmerski L. In “Solar materials Science”. New York: Academic Press; 1980. 508.
[12] Jaulmes S, Rivet J, Laruelle P. Acta Crystallogr 1977;B33:540.

13] Wang N. Neues Jahrb Min Monatsh; 1974. p.424.

[14] Hahn H, Klingen W, Ness P, Schulze H. Naturwissenschaften 1966;53:18.

[15] Bouaziz M, Amlouk M, Belgacem S. Thin Solid Films 2009;517:2527.

[16] Jaulmes S, Julien-Pouzol M, Rivet J, Jumas JC, Maurin M. Acta Crystallogr 1982;B38:51.

[17] Bouaziz M, Ouerfelli J, Amlouk M, Belgacem S. Phys Status Solidi 2007; 204:3354.

[18] Chalbaud LM, Delgado GD, Delgado JM. Mater Res Bull 1997;32:1371.

[19] Li B, Xie Y, Huang JX, Qian YT. J Solid State Chem 2000;153:170.

[20] Li Q, Ding Y, Liu XM, Qian YT. Mater Res Bull 2001;36:2649.

[21] Kuku TA, Fakolujo OA. Solar Energ Mater 1987;16:199.

[22] Amlouk A, Boubaker K, Amlouk M. Vacuum 2010;85:60.

[23] JCPDS (89-2877) for Cu2SnS3.

[24] Elidrissi B, Addou M, Regragui M, Mony C, Biougrine A, Kachouane A. Thin Solid Films 2000;358:40.

[25] Dghoughi L, Elidrissi B, Bernède C, Addou M, Lamrani MA, Regragui M, et al. Appl Surf Sci 2006;253:1823.

[26] Pankove JI. Optical processes in semiconductors. New York: Dover Publications Inc; 1975. 93.

[27] Schmidt J, Roscher HH, Labusch R. Thin Solid Films 1994;251:116.

[28] Guillen C, Herrero J. J Appl Phys 1992;71:5479.

29] Mott NF, Davis EA. Electronic processes in noncrystalline materials. clarendon: Oxford; 1971.

[30] Agilan S, Mangalaraj D, Narayandass SK, Rao GM, Velumani S. Vacuum 2010;84:1220. 